\title{
TNFSF11 wt Allele
}

National Cancer Institute

\section{Source}

National Cancer Institute. TNFSF11 wt Allele. NCI Thesaurus. Code C50965.

Human TNFSF11 wild-type allele is located within $13 q 14$ and is approximately $45 \mathrm{~kb}$ in length. This allele, which encodes tumor necrosis factor lig and superfamily member 11 protein, plays a role in osteoclast differentiation and activation. This allele also is involved in apoptotic signal transduction and regulation. 